\title{
Fetal topography of branches of the cervical and thoracic divisions of the vagus nerves
}

\author{
L. Ya. Lopushniak ${ }^{A, B, C}$, T. V. Khmara ${ }^{D}$, N. M. Palibroda ${ }^{\mathrm{E}}$, A. A. Shostenko ${ }^{\mathrm{E}}$, \\ O. M. Boichuk*F, A. O. Palamar ${ }^{\mathrm{E}}$
}

Higher State Educational Establishment of Ukraine “Bukovinian State Medical University”, Chernivtsi

A - research concept and design; B - collection and/or assembly of data; C - data analysis and interpretation; D - writing the article; $\mathrm{E}$ - critical revision of the article; $\mathrm{F}$ - final approval of the article

The study of age and individual anatomical variability of vagus nerves and their branches in different age periods of human ontogenesis causes interest among both morphologists and doctors of different specialties.

The aim of the study. To find out the topography of the cervical and thoracic divisions of the vagus nerves in human fetuses aged from $4^{\text {th }}$ to $10^{\text {th }}$ gestational months.

Materials and methods. The research was conducted on 75 preparations of human fetuses ranging from 81.0 to $375.0 \mathrm{~mm}$ in parietal-coccygeal length $(\mathrm{PCL})$ using methods of macro-microscopic dissection and morphometry.

Results. In human fetuses, the left vagus nerve is placed anteriorly to the left subclavian artery, then on the lateral surface of the Botallo's arterial duct and the aortic arch. In the neck region, the superior cardiac branch departs from the left vagus nerve and goes to the anterior surface of the left common carotid artery.

In the inferior part of the left common carotid artery, the superior cardiac branch gives off two branches: the middle one reaches the aortic arch wall, and the lateral one runs along the anterior surface of the left common carotid artery. The left recurrent laryngeal nerve departs from the left vagus nerve at the level of the inferior border of the aortic arch. The right vagus nerve passes from the right subclavian artery anteriorly and gives rise to the right recurrent laryngeal nerve, which continues inferiorly and posteriorly around the subclavian artery. The superior cardiac branch originates from the right vagus nerve at the level of the inferior border of the thyroid gland. The inferior cardiac branch departs inferiorly and medially from the right laryngeal nerve and is located on the right anterolateral surface of the trachea.

Conclusions. During the fetal period of human ontogenesis, age and individual anatomical variations of the branches of the cervical and thoracic vagus nerves is observed, which is manifested by the variability of the structure, asymmetry of the topography of the recurrent laryngeal nerves, bronchial, esophageal and cardiac branches. The left recurrent laryngeal nerve departs from the left vagus nerve at the level of the inferior border of the aortic arch, the right recurrent laryngeal nerve departs from the right vagus nerve at the level of the right subclavian artery. The esophageal nervous plexus is formed by esophageal branches of the vagus nerves, which then forms mainly the posterior vagal trunk. The anterior vagal trunk is a direct continuation of the left vagus nerve branches. The innervation of the aortic arch involves the common cardiac trunk, which is formed by the superior cardiac branch and the superior cardiac nerve and also anastomoses both with vagus nerve and with recurrent laryngeal nerves.

\section{Фетальна топографія гілок шийного та грудного відділів блукаючих нервів}

\section{^. Я. Аопушняк, Т. В. Хмара, Н. М. Паліброда, А. А. Шостенко, О. М. Бойчук, А. О. Паламар}

Мета роботи - з'ясувати топографію гілок шийного та грудного відділів блукаючих нервів у плодів людини 4-10 місяців.

Матеріали та методи. Дослідження здійснили на 75 препаратах плодів людини 81,0-375,0 мм тім'яно-куприкової довжини за допомогою методів макромікроскопічного препарування та морфометрії.

Результати. У плодів людини лівий блукаючий нерв розміщується спереду лівої підключичної артерії, потім на бічній поверхні артеріальної протоки Боталла та дуги аорти. У ділянці шиї від лівого блукаючого нерва відходить верхня серцева гілка, що прямує до передньої поверхні лівої загальної сонної артерії. У нижньому відділі лівої загальної сонної артерії верхня серцева гілка віддає дві гілки: присередню, що досягає стінки дуги аорти, та бічну, що йде уздовж передньої поверхні лівої загальної сонної артерії. На рівні нижнього краю дуги аорти від лівого блукаючого нерва відходить лівий поворотний гортанний нерв. Правий блукаючий нерв проходить спереду від правої підключичної артерії та віддає поворотний гортанний нерв, який огинає підключичну артерію знизу і ззаду. На рівні нижнього краю щитоподібної залози від правого блукаючого нерва відгалужується верхня серцева гілка. Від правого поворотного гортанного нерва відходить нижня серцева гілка, що прямує вниз і медіально та розташовується на правій передньобічній поверхні трахеї.

Висновки. Упродовж плодового періоду онтогенезу людини спостерігається вікова та індивідуальна анатомічна мінливість гілок шийного та грудного відділів блукаючих нервів, що проявляється варіабельністю будови, асиметрією топографії поворотних гортанних нервів, бронхових, стравохідних і серцевих гілок. Від лівого блукаючого нерва на рівні нижнього краю дуги аорти відходить лівий поворотний гортанний нерв. Правий поворотний гортанний нерв відходить від правого блукаючого нерва на рівні правої підключичної артерії. Стравохідні гілки блукаючих нервів утворюють стравохідне нервове сплетення, з якого формується переважно задній блукаючий стовбур. Передній блукаючий стовбур є безпосереднім продовженням гілок лівого блукаючого нерва. В іннервації дуги аорти бере участь загальний серцевий стовбур, що утворений верхньою серцевою гілкою та верхнім серцевим нервом, а також має зв'язки як із блукаючим, так і з поворотним гортанним нервами.
Key words: vagus nerve, anatomical variability, topography, fetus, human being.

Zaporozhye medical journal 2020; 22 (4), 495-501

*E-mail: olegb007@i.ua 
Киючевые слова: блужАающий нерв, анатомическая изменчивость, топография, плоА, человек.

Запорожский медицинский журнал 2020. T. 22, № 4(121) C. 495-501

\title{
Фетальная топография ветвей шейного и грудного отделов блуждающих нервов
}

\author{
^. Я. ヘопушняк, Т. В. Хмара, Н. М. Палиброда, А. А. Шостенко, О. М. Бойчук, А. А. Паламар \\ Цель работы - выяснить топографию ветвей шейного и грудного отделов блуждающих нервов у плодов человека 4-10
} месяцев.

Материалы и методы. Исследование проведено на 75 препаратах плодов человека 81,0-375,0 мм теменно-копчиковой длины с помощью методов макромикроскопического препарирования и морфометрии.

Результаты. У плодов человека левый блуждающий нерв размещается спереди левой подключичной артерии, а затем латеральнее артериального Боталлова протока и дуги аорты. В области шеи от левого блуждающего нерва отходит верхняя сердечная ветвь, которая направляется к передней поверхности левой общей сонной артерии. В нижнем отделе левой общей сонной артерии верхняя сердечная ветвь отдает две ветви: медиальную, которая достигает стенки дуги аорты, и латеральную, которая проходит вдоль передней поверхности левой общей сонной артерии. На уровне нижнего края дуги аорты от левого блуждающего нерва отходит левый возвратный гортанный нерв. Правый блуждающий нерв проходит спереди от правой подключичной артерии и отдает возвратный гортанный нерв, который огибает подключичную артерию снизу и сзади. На уровне нижнего края щитовидной железы от правого блуждающего нерва ответвляется верхняя сердечная ветвь. От правого возвратного гортанного нерва отходит нижняя сердечная ветвь, которая направляется вниз и медиально и располагается на правой переднебоковой поверхности трахеи.

Выводы. В течение плодного периода онтогенеза человека наблюдается возрастная и индивидуальная анатомическая изменчивость ветвей шейного и грудного отделов блуждающих нервов, которая характеризуется вариабельностью строения, асимметрией топографии возвратных гортанных нервов, бронхиальных, пищеводных и сердечных ветвей. От левого блуждающего нерва на уровне нижнего края дуги аорты отходит левый возвратный гортанный нерв. Правый возвратный гортанный нерв отходит от правого блуждающего нерва на уровне правой подключичной артерии. Пищеводные ветви блуждающих нервов образуют пищеводное нервное сплетение, из которого формируется преимущественно задний блуждающий ствол. Передний блуждающий ствол является непосредственным продолжением ветвей левого блуждающего нерва. В иннервации дуги аорты участвует общий сердечный ствол, который образован верхней сердечной ветвью и верхним сердечным нервом, а также имеет связи как с блуждающим, так и с возвратным гортанным нервами.

The vagus nerve is a main component of the parasympathetic part of the autonomic nervous system, which controls important functions of the body, including mood control, immune response, digestive process and heart rate [1-4].

The development of new methods of surgical interventions on the organs of the cervical and thoracic cavity, and also methods of analgesia and vagus stimulation is inextricably connected with the study of typical and variant anatomy of the branches of the cervical and thoracic divisions of vagus nerves. The vagus nerve can be located both dorsally and ventrally towards the common carotid artery.

Between 12 and 20 gestational weeks, the vagus nerve shifts to the ventrodorsal direction relatively to the common carotid artery [5-8].

The study of age and individual anatomical variability of the vagus nerves and their branches in different ages of human ontogenesis causes interest in both morphologists and doctors of different specialties $[9,10]$. Knowledge of the topography and possible branching of the recurrent laryngeal nerve allows to localize its branches during anterior cervical surgery, and also provides adequate resection of these branches in patients with spastic dysphonia [11,12].

An increased interest in further studying of structural organization of the anterior cervical area and mediastinum in health and pathology is determined by the growth in congenital and acquired diseases of these organs and structures $[13,14]$. Despite the high practical value, known scientific data on morphology of the larynx, thyroid and parathyroid glands, oesophagus, trachea, bronchi and adjacent structures in human fetuses of different age periods [15] do not solve all of the current problems of perinatal medicine and fetal surgery.

Therefore, we consider the research of correlative relationships of vagus nerves and their branches with adjacent organs and structures during the fetal period of human ontogenenesis to be relevant.

\section{Aim}

To find out the topography of the cervical and thoracic divisions of the vagus nerves in human fetuses aged from $4^{\text {th }}$ to $10^{\text {th }}$ gestational months.

\section{Materials and methods}

The study of the topographic and anatomical features of the branches of the cervical and thoracic divisions of the right and left vagus nerves was conducted in 75 preparations of human fetuses ranging from 81.0 to $375.0 \mathrm{~mm}$ in parietal-coccygeal length $(\mathrm{PCL})$ using the methods of macro- and microscopic dissection and morphometry. The study included only cases where the cause of death was not related to pathology of the organs and neurovascular formations of the cervical and thoracic cavity. The preparations of fetuses weighing more than $500.0 \mathrm{~g}$ were studied at Chernivtsi Regional Children Pathoanatomical Bureau under a Cooperation agreement. Preparations of fetuses from the M. H. Turkevych Museum of the Department of Human Anatomy of HSEE of Ukraine "Bukovinian State Medical University" were also used for studies.

The studies were performed in compliance with the general bioethical provisions of the Council of Europe Convention on Human Rights and Biomedicine (from April 4, 1997), the World Health Association Declaration of Helsinki on Ethical Principles for Scientific Medical Research with Human Participation (1964-2013), order of the Ministry of Health Care of Ukraine No. 690 of September 23, 2009, and taking into account the methodological recommendations of the Ministry of Health Care of Ukraine "Procedure for the removal of biological objects from deceased persons whose bodies are subject to forensic examination and pathoanatomical research, 
for scientific purposes" (2018). The Board on Biomedical Ethics of the HSEE of Ukraine "Bukovinian State Medical University" found no violations of moral norms during scientific research.

\section{Results and discussion}

At the beginning of the fetal period of human ontogenesis (fetuses of $81.0-95.0 \mathrm{~mm} \mathrm{PCL}$ ), the right vagus nerve is located behind the brachiocephalic trunk. The left vagus nerve in the superior mediastinum is located anteriorly to the left subclavian artery, then on the lateral surface of the Botallo's arterial duct and the aortic arch. At the level of the inferior border of the aortic arch to the left from the vagus nerve, the left recurrent laryngeal nerve departs. Laterally to the left vagus nerve, on the anterior left surface of the aortic arch, the left diaphragmatic (phrenic) nerve and the pericardiophrenic vessels are placed. After departing the left recurrent laryngeal nerve, the left vagus nerve passes into the fissure between the aortic arch and the left pulmonary artery to the posterior surface of the left lung hilum. In the projection of the vertebral column, the superior border of the left lung hilum corresponds to the midline of the T3 vertebra and the inferior border to the T5 vertebra. At the level of the inferior border of the left lung hilum, the left vagus nerve moves to the anterior wall of the esophagus.

At the level of the right sternoclavicular joint, the $3.0 \mathrm{~mm}$ to the right of the trachea, there is a place of the brachiocephalic trunk bifurcation to the right common carotid and right subclavian arteries. The right vagus nerve extends anteriorly from the right subclavian artery and gives rise to the right recurrent laryngeal nerve, which loops under the right subclavian artery behind. Then the right vagus nerve runs behind the right brachiocephalic and superior vena cava, pass towards the posterior surface of the right lung hilum and at the level of the inferior border of the right main bronchus courses to the posterior surface of the esophagus and gives off branches to the esophageal plexus.

In the fetuses aged from $5^{\text {th }}$ to $8^{\text {th }}$ month $(135.0$ $310.0 \mathrm{~mm} \mathrm{PCL})$, the right vagus nerve in the neck descends on the posterolateral surface of the right common carotid artery, with the internal jugular vein located in front and outside of the nerve. Having reached the level of the right subclavian artery, the right vagus nerve passes between it and the internal jugular vein. At the level of the inferior border of the thyroid gland, the superior cardiac branch originates from the right vagus nerve. The latter goes down and innervates the anterior surface of the right common carotid artery. At $2.8 \pm 0.8 \mathrm{~mm}$ above the level of the right subclavian artery, the superior cardiac branch gives off 2-3 branches: the middle that intersects the anterior surface of the initial compartment of the right common carotid artery and passes to its posterior surface; and 1-2 lateral branches, downward and extending branches to the brachiocephalic trunk and posterior surface of the right subclavian artery. Then, the lateral branches pass on the external border of the brachiocephalic trunk and gradually enter its posterior surface reaching the level of the right pulmonary artery discharge.

At the beginning, the superior cardiac branch (depressor) runs downwards in isolation, and at the distance of $1.3 \pm 0.25 \mathrm{~mm}$ the superior cardiac nerve joins it. The latter is represented by $1-3$ columns. In rare cases (fetuses of

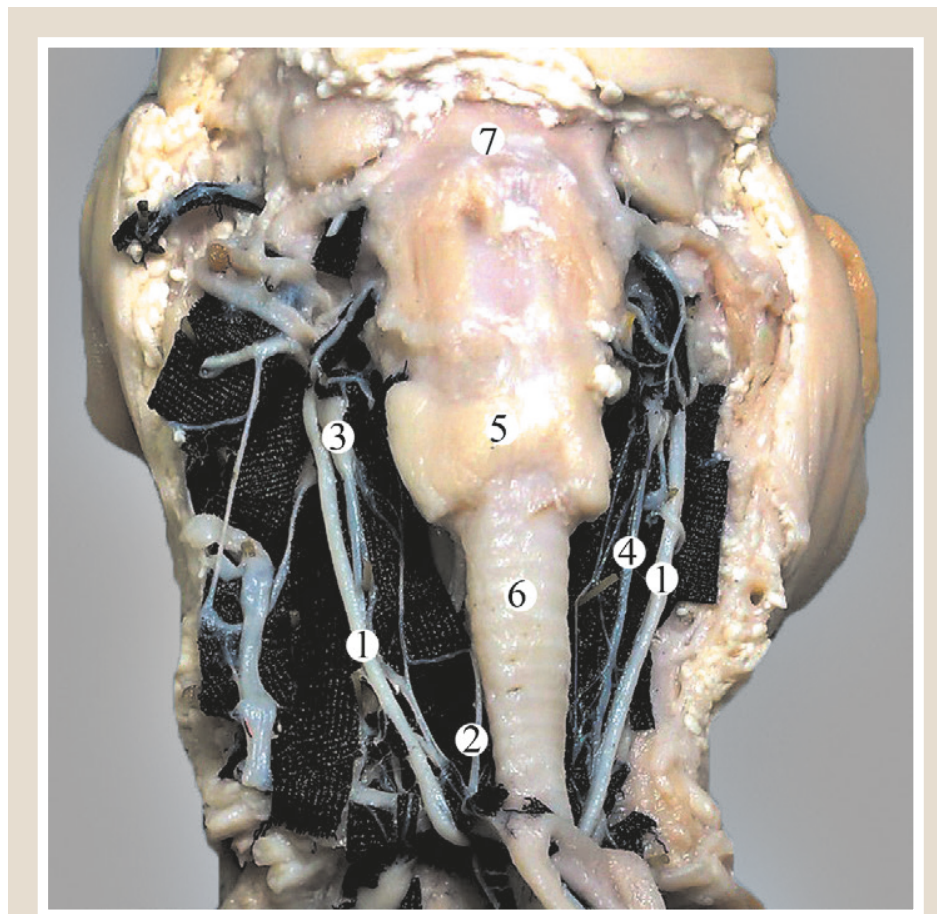

Fig. 1. Organs and structures of the neck of the fetus of $155.0 \mathrm{~mm} \mathrm{PCL}$. Gross specimen. Img. ×3.5:

1: vagus nerves; 2: right recurrent laryngeal nerve; 3 : superior cervical ganglia; 4: superior cervical cardiac nerves; 5: aortic arch; 6: branches from the common cardiac trunk to the aortic arch; 7: hyroid gland; 8: trachea; 9: hyoid bone.

155.0, 190.0, 275.0 and $310.0 \mathrm{~mm} \mathrm{PCL),} \mathrm{the} \mathrm{depressor} \mathrm{is}$ represented by a rather thin branch that goes to the superior cardiac nerve starting from the superior or middle cervical node. As a result, the common cardiac trunk is formed containing more sympathetic than parasympathetic fibers. The common cardiac trunk goes then caudally, anastomoses with the vagus and the recurrent laryngeal nerves, and in the area of the aortic arch, as a rule, gives off the anterior and posterior branches, leading to the corresponding wall of the aortic isthmus (Fig. 1). A part of the branches of the common cardiac trunk continues into the cardiac plexus. It should be noted that the stellate ganglion gives off $2-6$ branches to the aorta arch. These branches surround the subclavian artery anastomosing with each other on its way, as well as to branches of the vagus and the recurrent laryngeal nerves. It is also worth noting that single branches from the $3^{\text {rd }}-4^{\text {th }}$ superior cervical ganglia also reach the aortic arch.

The right recurrent laryngeal nerve originates from the right vagus nerve at the level of its intersection with the right subclavian artery. Then the right recurrent laryngeal nerve deflects medially, loops under the right subclavian artery and travels upwards to the trachea and larynx. From the right recurrent laryngeal nerve, the inferior cardiac branch extends downwards and medially and is located on the right anterior surface of the trachea. The superior vena cava is located in front of the inferior cardiac branch, and medially - the brachiocephalic trunk and the ascending part of the aorta. The inferior cardiac branch is divided into the medial and lateral branches at the level of the branch of the right main bronchus arising from the trachea. The middle branch is continuation of the inferior cardiac 


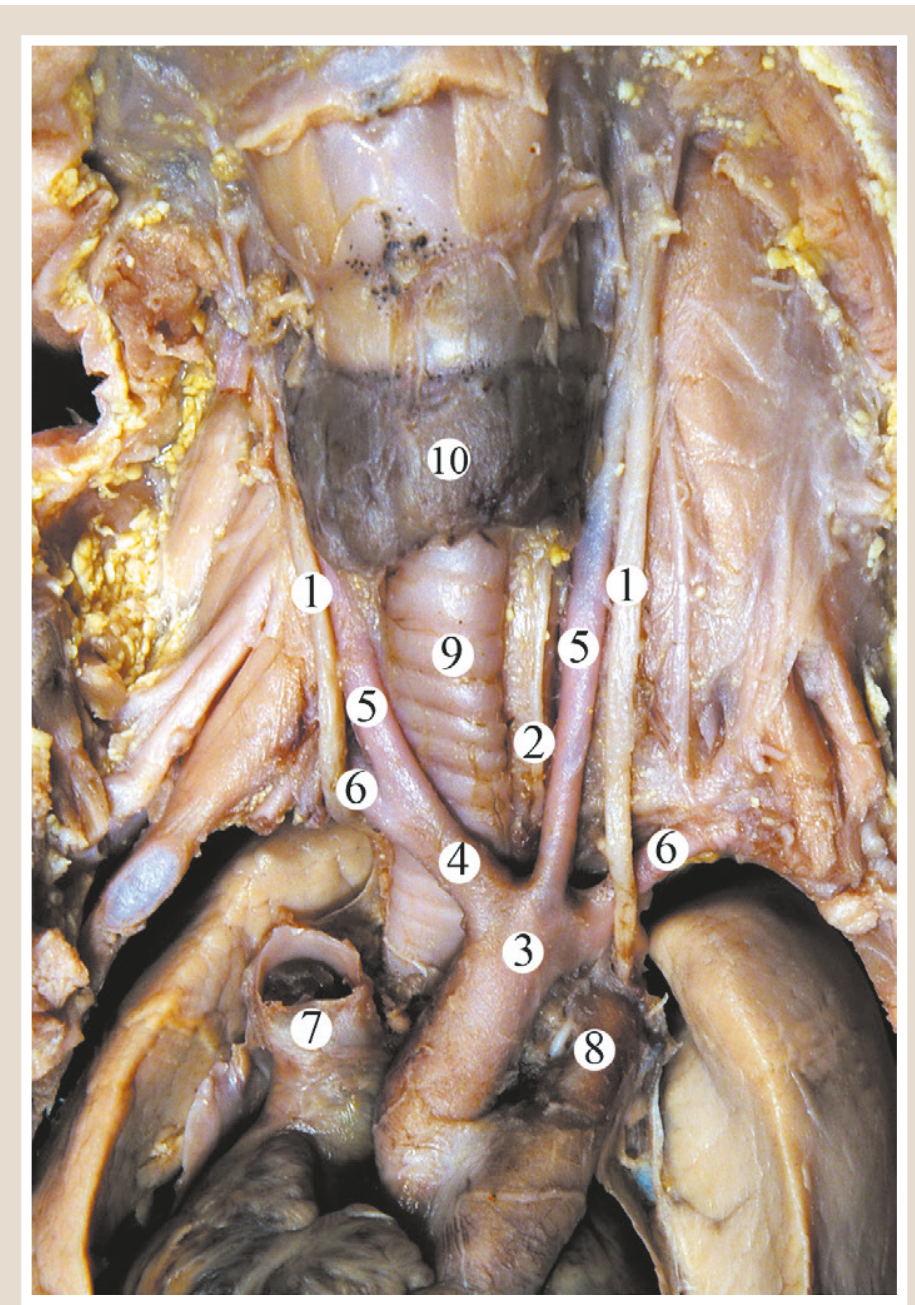

Fig. 2. Organs and structures of the neck and superior mediastinum of the fetus of $185.0 \mathrm{~mm} \mathrm{PCL}$. Gross specimen. Img. $\times 3.5$ :

1: vagus nerves; 2 : left recurrent laryngeal nerve; 3 : aortic arch; 4: brachiocephalic trunk; 5: common carotid arteries; 6: subclavian arteries; 7 : superior vena cava; 8: pulmonary trunk; 9: trachea; 10: thyroid gland. they anastomose with each other and, finally, with the right anterior pulmonary plexus. At the level of the inferior border of the right lung hilum, the right vagus nerve gives off, as a rule, 2 large branches - anterior and posterior, sometimes (fetuses of 178.0, 190.0, 290.0, and $310.0 \mathrm{~mm} \mathrm{PCL)} \mathrm{-}$ 3-4 branches. The smaller branches, which depart from the large ones, are located on the anterior and posterior surfaces of the esophagus. The esophageal branches are originated form the esophageal nervous plexus. The right vagus nerve, after branching of the esophageal branches, usually passes into the posterior vagal trunk.

In the superior mediastinum, the left vagus nerve extends over the anterior surface of the aortic arch. It should be noted that in the fetuses of $185.0 \mathrm{~mm} \mathrm{PCL}$, both the right and left vagus nerves cross the anterior surface of the corresponding subclavian artery when passing into the thoracic cavity. In the region of the neck, the superior cardiac branch departs from the vagus nerve and runs to the anterior surface of the left common carotid artery. In the inferior part of the left carotid artery, the superior cardiac branch gives off two branches: the middle one that reaches the walls of the aortic arch and the lateral which runs along the anterior surface of the left common carotid artery. At the location of adjacent to the left aortic arch, the left vagus nerve gives rise to the left recurrent laryngeal nerve, which loops the aortic arch from below, going upwards on the trachea lateral surface, and then passes into the tracheo-esophageal groove (Fig. 2).

In the superior mediastinum, the left vagus nerve is separated from the diaphragmatic nerve by the left superior intercostal vein, which flows into the left brachiocephalic vein. At the level of the aortic arch, from the left vagus nerve, mainly 3-4 branches go to the anterior surface of the left lung hilum branching and connecting to each other, forming the anterior pulmonary plexus. Separate branches reaching the hilum of the left lung pass to the mediastinal surface and branching in the subpleura. Middle and lateral branches were found in the left lung hilum area on the anterior surface of the left pulmonary artery among the branches of the left vagus nerve. The latter runs to the hilum of the left lung along the wall of the left pulmonary artery and, partially, the left superior pulmonary vein. Some branches descend to the anterior surface of the superior pulmonary vein, curve around it and run along its posterior wall to the heart. Two middle branches, as a rule, go on the anterior surface of the left pulmonary artery inferior border and penetrate the pericardium. One of the middle branches passes through the anterior surface of the left pulmonary artery, and then the pulmonary trunk and gives off branches to their walls. The second middle branch at the level of the left pulmonary artery gives off branches to the hilum of the left lung, after which it returns medially and goes to the left atrium wall at the level of the superior border of the left auricle. Among the left anterior pulmonary plexus branches, which go to the heart, single nerve branches which pass behind the left pulmonary artery to the anterior surface of the left atrium and connect with the branches of the right anterior pulmonary plexus are identified.

It should be noted that in $96 \%$ of the studied preparations of human fetuses, the left vagus nerve is adjacent to the middle border of the superior left pulmonary artery, while the right vagus nerve is $5.7 \pm 1.5 \mathrm{~mm}$ medially to the border of the right pulmonary veins. 
In the fetuses, $210.0 \mathrm{~mm} \mathrm{PCL}$ in the neck area, both the right and left vagus nerves descend within the cervical neurovascular bundle, it is placed between the internal jugular vein and the common carotid artery, with the left vagus nerve being slightly behind, at the back of these vessels (Fig. 3). Within the superior mediastinum, the right and left vagus nerves pass along the anterior surface of the corresponding subclavian artery, the esophagus is placed in the middle sagittal plane, while the trachea is shifts to the right. The length of the trachea within the superior mediastinum is $16.0 \mathrm{~mm}$.

The superior vena cava flows $8.5 \mathrm{~mm}$ long into the posterior extended part of the right atrium. The superior vena cava is formed by the union of the left and right brachiocephalic veins behind the junction of the right 2 nd costal cartilage with the sternum. The length of the right brachiocephalic vein is $7.0 \mathrm{~mm}$ and the length of the left vein is $14.5 \mathrm{~mm}$. There are the aortic arch branches behind the left brachiocephalic vein. The brachiocephalic trunk is located in front of the trachea and adjacent to the tracheal rings VIII and VII. The superior vena cava is directed downwards, at level of the III right costal cartilage enters the pericardiac cavity, draining into the right atrium at the level of the IV right costal cartilage junction with the sternum. The terminal section of the superior vena cava is located intrapericardially. To the right of the superior vena cava, there is the mediastinal part of the parietal pleura and the right diaphragmatic nerve, to the left - the ascending part of the aorta, $12.5 \mathrm{~mm}$ long.

The left diaphragmatic nerve overlies the heart arcuately. The aorta is covered with serous pericardium until the ascending part becomes the aortic arch. The serous pericardium continues from the initial aortic arch to the pulmonary trunk. The serous membrane is seen at a distance of $4.0 \mathrm{~mm}$ on the anterior surface of the left pulmonary artery. The pericardium covers the initial section of the right pulmonary artery and its inferior and anterior surfaces in the area of the superior vena cava and the aortic arch. The pericardial fold extends through the superior vena cava from left and top, from right to left, resulting in that the superior vena cava is covered with pericardium on the right side less than the left one. The pulmonary veins are covered with serous pericardium at the front and both sides.

In the fetuses of $240.0 \mathrm{~mm} \mathrm{PCL}$, the right and left vagus nerves slightly adjoin the lateral surfaces of the esophagus below the hilum of the corresponding lung. Two branches located on the anterior surface of the esophagus are originating from the left vagus nerve. Two branches located on the anterior surface of the esophagus arise from the left vagus nerve. The superior thoracic section of the esophagus in the superior mediastinum is adjacent to the anterior surface of the T4 vertebrae. There are the trachea and its bifurcation in front of the esophagus. At the level of the inferior border of the T4 vertebral body, the esophagus is displaced to the left. The aortic arch, $9.0 \mathrm{~mm}$ long, with upwards convexity extends obliquely from front to back and left, bending at the initial left main bronchus. There is a bifurcation of the trachea (at the level of the inferior border of the T2 vertebral body) behind the aortic arch. The brachiocephalic trunk, left common carotid artery, and left subclavian artery arise from the convex semicircular aortic arch. The brachiocephalic trunk leaves up and to the right, the left brachiocephalic vein runs in front of it, and

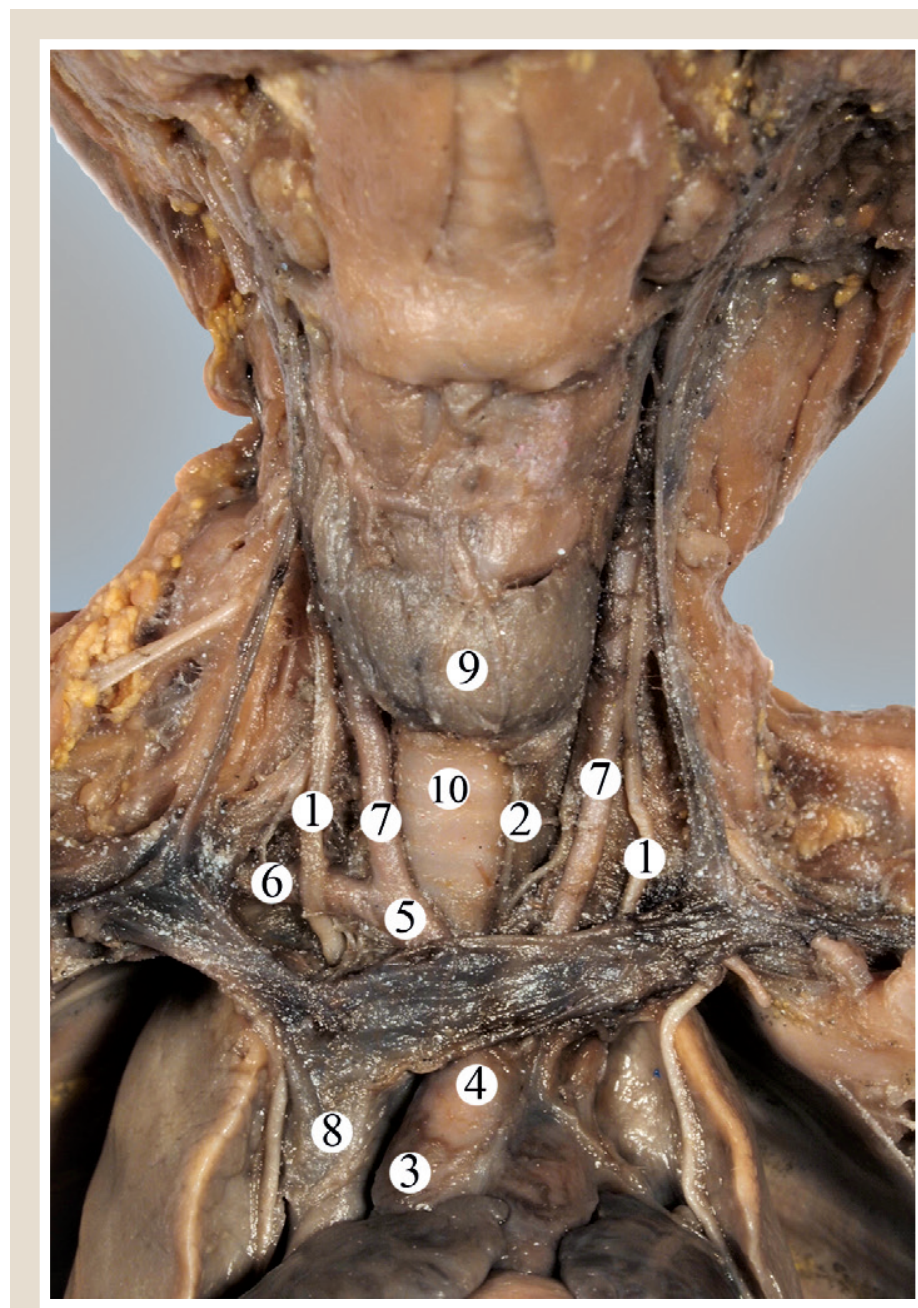

Fig. 3. Organs and structures of the neck and superior mediastinum of the fetus of $210.0 \mathrm{~mm} \mathrm{PCL}$ Gross specimen. Img. $\times 1.8$ :

1: vagus nerves; 2 : left recurrent laryngeal nerve; $3:$ the ascending part of the aorta; 4 : aortic arch; 5: brachiocephalic trunk; 6 : right subclavian artery; 7: common carotid arteries; 8: superior vena cava; 9: thyroid gland; 10: trachea; 11: internal jugular veins.

the trachea - behind. The right vagus nerve in the superior mediastinum is adjacent to the lateral surface of the trachea. Just above the bifurcation of the trachea (mid-body of the T2 vertebra), two thin branches extend from the right vagus nerve and reach the anterior surface of the trachea and right main bronchus, continuing to the hilum of the right lung. At the level of the lung hilums, two branches from the vagus nerve innervate the anterior and lateral surfaces of the esophagus. The left vagus nerve in the superior mediastinum is located anteriorly and medially to the left subclavian artery. At the location of adjacent to the left aortic arch, the left vagus nerve gives rise to the left recurrent laryngeal nerve that loops under the aortic arch running upwards on the lateral surface of the trachea (Fig. 4). Below the aortic arch, three branches extend from the vagus nerve to the hilum of the left lung. At the level of the inferior border of the left lung hilum, the vagus nerve innervates the lateral surface of the esophagus and gives off two branches.

In the fetuses of $290.0 \mathrm{~mm} \mathrm{PCL}$, the left vagus nerve at the level of the left lung hilum gives off five branches of almost the same thickness, which innervate the hilum of 


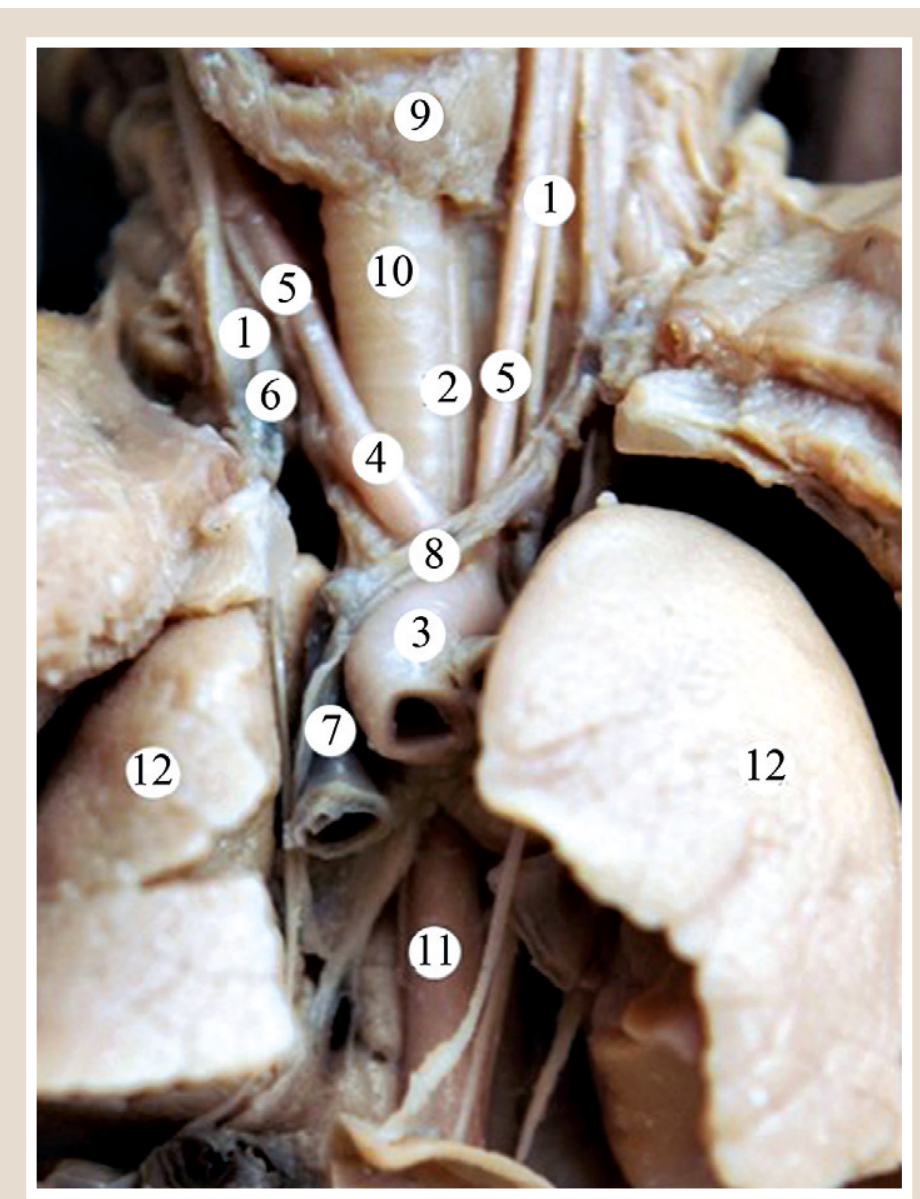

Fig. 4. Organs and structures of the neck and thoracic cavity of the fetus of $240.0 \mathrm{~mm} \mathrm{PCL}$. Gross specimen. Img. $\times 2.3$ :

1: vagus nerves; 2 : left recurrent laryngeal nerve; 3 : aortic arch; 4: brachiocephalic trunk; 5 : common carotid arteries; 6 : right subclavian artery; 7 : superior vena cava; 8 : left brachiocephalic vein; 9 : thyroid gland; 10: trachea; 11: esophagus; 12: lungs.

the left lung. The main trunk of the vagus nerve at the level of the left pulmonary vein is separated into anterior and posterior branches which run to the lateral surface of the osophagus. Thinner branches originate from the latter, located on both the anterior and posterior surfaces of the esophagus.

In the fetuses of 315.0-345.0 mm PCL, the left vagus nerve at the level of the inferior border of the inferior left pulmonary vein gives off two branches: the thicker is anterior one and the thinner is posterior. The anterior branch is directed along the anterior surface of the esophagus to the diaphragm, giving off two thin branches to its wall. The posterior branch is located on the posterior surface above the diaphragm portion of the esophagus anastomosing with the posterior branch of the right vagus nerve. The right vagus nerve at the level of the hilum of the right lung gives off three branches, and then at the level of the inferior border of the right lung hilum is separated into two branches: the thinner anterior one and the thicker posterior. The posterior branch anastomoses with the posterior branch of the left vagus nerve above the diaphragm, forming a posterior vagal trunk. The anterior branches of both the right and left vagus nerves are involved in the anterior vagal trunk formation.
In the fetuses of $360.0-375.0 \mathrm{~mm} \mathrm{PCL}$, the left vagus nerve giving off three branches to the left lung hilum, is adjacent to the anterior surface of the esophagus, where the nerve leaves four branches. The left vagus nerve, after leaving the esophagus branches enters the anterior vagal trunk. The right vagal trunk is formed by two long branches within the esophageal opening of the diaphragm. The right vagus nerve gives off three branches below the level of the right main bronchus: one short and two long. One of the long branches reaches the right lateral surface of the esophagus close to the diaphragm on the posterior surface of the organ. The second long branch is located on the anterior surface near the diaphragm adjacent to the lateral surface of the esophagus.

At the end of the fetal period of ontogenesis, the branches of the anterior right and left pulmonary plexuses give off single branches to the pleura, bronchi, pulmonary artery and pulmonary veins before entering the hilum of the corresponding lung. In the fetuses of 280.0, 307.0 and 310.0 $\mathrm{mm}$ in PCL, branches of diaphragmatic nerves extend to the anterior pulmonary plexus branches.

Our findings indicate that the formation of the topography of the cervical and thoracic division of the right and left vagus nerves is morphologically related to the formation of the larynx, esophagus, trachea, thyroid gland, heart and hilum components of the corresponding lung. During the fetal period of ontogenesis, intensive formation of the anterior pulmonary plexuses on the anterior surface of the hilum of the right and left lungs occurs and their anastomoses with the cardiac plexuses are formed. We have found the variability of the topography of the right and left recurrent laryngeal nerves, the superior and inferior cardiac, bronchial and esophageal branches of the vagus nerves, which is consistent with the previous data [9].

According to our study, the main trunk of the left vagus nerve at the level of the left inferior pulmonary vein gives off 2-3 branches that innervate the esophagus lateral surface. The smaller branches located on the anterior, lateral and posterior surfaces of the esophagus, are derived from the latter ones. After leaving the esophageal branches, the left vagus nerve, as a rule, passes into the anterior vagal trunk, which is consistent with the works of other authors [16].

\section{Conclusions}

1. During the fetal period of human ontogenesis, age-related and individual anatomical variations of the branches of the cervical and thoracic divisions of the vagus nerves are observed. It is manifested by the variability of the structure, asymmetry of the topography of the recurrent laryngeal nerves, bronchi, esophageal and cardiac branches.

2. In the human fetuses, the left vagus nerve passes across the anterior surface of the left subclavian artery and at the level of the inferior border of the aortic arch leaves the left recurrent laryngeal nerve which loops under the aortic arch and then runs upwards on the trachea lateral surface. The right vagus nerve is located behind the brachiocephalic trunk and at the level of the right sternoclavicular joint extends anteriorly to the right subclavian artery and gives the right recurrent laryngeal nerve, which reaches the neck looping around the subclavian artery behind. 
3. The esophageal nervous plexus is formed by esophageal branches of the vagus nerves, which then forms mainly the posterior vagal trunk. The anterior vagal trunk is a direct continuation of one of the left vagus nerve branches located on the anterior surface of the esophagus.

4. The common cardiac trunk described in our work is involved in the innervation of the aortic arch in some fetuses, and this trunk is formed by the superior cardiac branch and the superior cardiac nerve and contains mainly sympathetic and parasympathetic fibers. The common cardiac trunk anastomoses with both the vagus and the recurrent laryngeal nerves.

Conflicts of interest: authors have no conflict of interest to declare. Конфлікт інтересів: віАсутній.

Надійшла Ао реАакції / Received: 25.11.2019

Після Аоопрацювання / Revised: 13.01.2020

Прийнято Ао Аруку / Accepted: 20.01.2020

\section{Information about authors:}

Lopushniak L. Ya., MD, Postgraduate Student of the Department of Human Anatomy named after M. H. Turkevych, Higher State Educational Establishment of Ukraine "Bukovinian State Medical University", Chernivtsi.

Khmara T.V., MD, PhD, DSc, Professor of the Department of Human Anatomy named after M. H. Turkevych, Higher State Educational Establishment of Ukraine "Bukovinian State Medical University", Chernivtsi.

Palibroda N. M., MD, PhD, Associate Professor of the Department of Internal Medicine and Infectious Diseases, Higher State Educational Establishment of Ukraine "Bukovinian State Medical University", Chernivtsi.

Shostenko A. A., MD, PhD, Assistant of the Department of Pediatric Dentistry, Higher State Educational Establishment of Ukraine "Bukovinian State Medical University", Chernivtsi. Boichuk O. M., MD, PhD, Assistant of the Department of Human Anatomy named after M. H. Turkevych, Higher State Educational Establishment of Ukraine "Bukovinian State Medical University", Chernivtsi.

Palamar A. O., PhD, Assistant of the Department of Pharmacy, Higher State Educational Establishment of Ukraine "Bukovinian State Medical University", Chernivtsi.

\section{Відомості про авторів:}

ヘопушняк ^. Я., аспірант каф. анатомії юАини імені М. Г. Туркевича, ВАНЗ України “Буковинський Аержавний медичний університет", м. Чернівці.

Хмара Т. В., А-р меА. наук, професор каф. анатомії ююдини імені М. Г. Туркевича, ВАНЗ України «Буковинський Аержавний медичний університет», м. Чернівці.

Паліброда Н. М., канд. меА. наук, Аоцент каф. внутрішньої меАицини, ВАНЗ України “Буковинський Аержавний меАичний університет", м. Чернівці.

Шостенко А. А., канА. меА. наук, асистент каф. стоматології Аитячого віку, ВАНЗ України «Буковинський Аержавний медичний університет", м. Чернівці.

Бойчук О. М., канА. меА. наук, асистент каф. анатомії люАини імені М. Г. Туркевича, ВАНЗ України «Буковинський Аержавний медичний університет", м. Чернівці. Паламар А. О., канА. фарм наук, асистент каф. фармації, ВАНЗ України “Буковинський Аержавний меАичний університет, м. Чернівці.

\section{Сведения об авторах:}

Лопушняк $\Lambda$. Я., аспирант каф. анатомии человека имени Н. Г. Туркевича, ВГУз Украины «Буковинский государственный медицинский университет”, г. Черновцы.

Хмара Т. В., А-р меА. наук, профессор каф. анатомии человека имени Н. Г. Туркевича, ВГУЗ Украины «Буковинский государственный медицинский университет», г. Черновцы.
Палиброда Н. М., канд. меА. наук, Аоцент каф. внутренней медицины, ВГУЗ Украины “Буковинский государственный медицинский университет", г. Черновцы.

Шостенко А. А., канА. меА. наук, ассистент каф. стоматологии Аетского возраста, ВГУЗ Украины "Буковинский государственный медицинский университет", г. Черновцы. Бойчук О. М., канА. меА. наук, ассистент каф. анатомии человека имени Н. Г. Туркевича, ВГУЗ Украины “Буковинский государственный медицинский университет", г. Черновцы. Паламар А. А., канА. фарм. наук, ассистент каф. фармации, ВГУЗ Украины “Буковинский государственный меАицинский университет", г. Черновцы.

\section{References}

[1] Breit, S., Kupferberg, A., Rogler, G., \& Hasler, G. (2018). Vagus Nerve as Modulator of the Brain-Gut Axis in Psychiatric and Inflammatory Disorders. Frontiers in Psychiatry, 9, Article 44. https://doi.org/10.3389/ fpsyt.2018.00044

[2] Carabotti, M., Scirocco, A., Maselli, M. A., \& Severi, C. (2015). The gut-brain axis: interactions between enteric microbiota, central and enteric nervous systems. Annals of gastroenterology, 28(2), 203-209.

[3] Hammer, N., Glätzner, J., Feja, C., Kühne, C., Meixensberger, J., Planitzer, U., Schleifenbaum, S., Tillmann, B. N., \& Winkler, D. (2015). Human vagus nerve branching in the cervical region. PLOS ONE, 10(2), Article e0118006. https://doi.org/10.1371/journal.pone.0118006

[4] Seki, A., Green, H. R., Lee, T. D., Hong, L., Tan, J., Vinters, H. V., Chen, P. S., \& Fishbein, M. C. (2014). Sympathetic nerve fibers in human cervical and thoracic vagus nerves. Heart rhythm, 11(8), 14111417. https://doi.org/10.1016/j.hrthm.2014.04.032

[5] Inamura, A., Nomura, S., Sadahiro, H., Imoto, H., Ishihara, H., \& Suzuki, M. (2017). Topographical features of the vagal nerve at the cervical level in an aging population evaluated by ultrasound. Interdisciplinary Neurosurgery, 9, 64-67. https://doi.org/10.1016/j.inat.2017.03.006

[6] Miyake, N., Hayashi, S., Kawase, T., Cho, B. H., Murakami, G., Fujimiya, M. \& Kitano, H. (2010). Fetal Anatomy of the Human Carotid Sheath and Structures In and Around It. The Anatomical Record, 293(3), 438-445. https://doi.org/10.1002/ar.21089

[7] Kamani, D., Potenza, A. S., Cernea, C. R., Kamani, Y. V., \& Randolph, G. W. (2015). The nonrecurrent laryngeal nerve: anatomic and electrophysiologic algorithm for reliable identification. Laryngoscope, 125(2), 503-508. https://doi.org/10.1002/lary.24823

[8] Yuan, H., \& Silberstein, S. D. (2016). Vagus Nerve and Vagus Nerve Stimulation, a Comprehensive Review: Part I. Headache, 56(1), 71-78. https://doi.org/10.1111/head.12647

[9] Halychanska, O. M. \& Khmara, T. V. (2013). Correlative interrelations of the vagus nerves in human fetusesand newborns. VISNYK VDNZU "Ukrainska medychna stomatolohichna akademiia», 13(4), 107-111.

[10] Gürleyik, E. (2015). Non-recurrent nerve from the vagus anterio-medially located in the carotid sheath. Ulusal cerrahi dergisi, 31(3), 182-184. https://doi.org/10.5152/UCD.2015.2854

[11] Donatini, G., Carnaille, B., \& Dionigi, G. (2013). Increased detection of non-recurrent inferior laryngeal nerve (NRLN) during thyroid surgery using systematic intraoperative neuromonitoring (IONM). World journal of surgery, 37(1), 91-93. https://doi.org/10.1007/s00268-012-1782-y

[12] Scheid, S. C., Nadeau, D. P., Friedman, O., \& Sataloff, R. T. (2004). Anatomy of the thyroarytenoid branch of the recurrent laryngeal nerve. Journal of voice, 18(3), 279-284. https://doi.org/10.1016/j. jvoice.2003.08.003

[13] Ellwanger, J. H., da Costa Rosa, J. P., dos Santos, I. P., da Rosa, H. T., Jotz, G. P., Xavier, L. L., \& de Campos, D. (2013). Morphologic evaluation of the fetal recurrent laryngeal nerve and motor units in the thyroarytenoid muscle. Journal of voice,27(6), 668-673. https:// doi.org/10.1016/j.jvoice.2013.07.004

[14] Lee, J. H., Cheng, K. L., Choi, Y. J., \& Baek, J. H. (2017). High-resolution Imaging of Neural Anatomy and Pathology of the Neck. Korean journal of radiology, 18(1), 180-193. https://doi.org/10.3348/kj.2017.18.1.180

[15] Nerurkar, N. K. \& Dighe, S. N. (2019). Anatomical Course of the Thyroarytenoid Branch of the Recurrent Laryngeal Nerve. Laryngoscope, 129(3), 704-708. https://doi.org/10.1002/lary.27491

[16] Marchuk, O. F. (2008).Topohrafiia stravokhodu v 4-5-misiachnykh plodiv [Topography of the esophagus 4-5-month old fetuses]. Klinichna anatomiia ta operatyvna khirurhiia, 7(1), 34-38. [in Ukrainian]. 